\title{
From the Editor's Keyboard:
}

...cue music...Music? Music! This issue marks the addition of a new feature for the Bulletin: reviews of music CDs. We begin with a review essay by Sonia Seeman, of two CDs of music from the Balkans, music that reflects the traditions and influences of both the former Ottoman Empire and Western Europe. More reviews are forthcoming, and our goal is to make CD reviews an integral part of the Bulletin mix. Reviews of CDs add to an ongoing effort to publish research on the music of the Middle East and Muslim regions, and this issue features Karim Gillani's essay on the Ismaili Ginan tradition.

I also call your attention to Sobhi Rayan's thoughtful essay on al-Ghazali's method of doubt, and Nadya Sbaiti and Sara Scalenghe's informative work on Lebanese archives outside of Beirut. Part one (vol. 37, no. 1: 68-79), covered archives in Beirut. This issue also contains more than 40 reviews and review essays for your perusal and consideration.

I hope you enjoy this issue of the Bulletin, and as always, I encourage you to write a letter to the editor regarding any of the content. I also urge you to consider submitting a manuscript to the Bulletin. As a MESA member, this is your journal-I hope you see the Bulletin as your journal of choice for discussion of research methodology, sources, new approaches, controversies in the field, pedagogy and yes: music! 